\title{
Development of functional nourishing cream using fulvic acid
}

\author{
ByungWan Jo ${ }^{1}$, JunHo Jo ${ }^{1 *}$, Yunsung Lee ${ }^{1}$ \\ ${ }^{1}$ Department of Civil and Environmental Engineering, Hanyang University, 222 Wangsimni-ro, Seongdong-gu, \\ Seoul, 04763, Republic of Korea.
}

\begin{abstract}
Fulvic acid is a natural material contained within soil that contains an ample amount of minerals and various functionalities such as antioxidation, currently making it a popular choice as a raw material for food, medicine and cosmetic products. Therefore, the research is to develop functional cosmetics for the prevention of skin aging by using fulvic acid, a natural humic substance that is effective in improving whitening and wrinkle. However, adenosine, edelweiss-cultured natural extracts, Niacinamide, Bio-AHP 500H, etc. are mixed in the cream to minimize the effective chelate reaction. Also,stable production was proposed including weight-measuring scale, stirring AGi adjustment and etc. that are performed for a smooth chelate reaction of crude fulvic acid solution. Furthermore, various tests such as including a skin cell safety test, collagen synthesis test, wrinkle improvement-related gene expression analysis test, anti-aging and antioxidative effect test and melanin synthesis inhibition test are performed and showed an outstanding level of performance in all tests. Finally, the cream has been tested on 5 items, criteria of quality assessment in cosmetic testing by the Ministry of Food \& Drug safety, which are lead, arsenic, mercury, methanol, etc. and have passed all the inspection criteria.
\end{abstract}

Key words: Fulvic Acid, Functional Nourishing Cream, Cosmetic.

\section{Introduction}

Fulvic acid, a natural material contained within soil, absorbs toxic substances penetrated into the soil to transform them into pure materials and also functions to ionize minerals with amino acids, creating organic minerals [1]. In an organic electrolyte state, it has a small amount of molecules and is easily dissolved, and also combines minerals and nutrients to the fulvic acid molecular structure. Nutrients that have been cheated by fulvic acid are in an ideal, natural state, which enables them to mutually react with living cells and expedites absorption. These nutrients are transferred to target cells and, simultaneously, makes the entire process of transport into the cells and usage smoother.

It is difficult to extract fulvic acid whose effects hinge significantly on the concentration level [2][3][4]. Fulvic acid contains an ample amount of minerals and various functionalities such as antioxidation, currently making it a popular choice as a raw material for food, medicine and cosmetic products [2][3][4].

This research aims to find a suitable technique to induce an effective chemical chelate reaction among materials by using a crude, pure and high-quality drinkable fulvic acid imported from Japan's Fromearth and authorized for health treatment purposes in order to develop a functional nourishing cream for whitening and prevention of wrinkles and aging by using fulvic acid, a natural plant nutrient that has excellent anti-aging properties, antioxidation with proven effects in skin aging prevention, skin elasticity improvement and skin moisturizing enhancement.

Because fulvic acid, an excellent ingredient that can be used to organize and regenerate skin, cannot obtain the expected effects if the amount of mixture is insufficient, it is paramount to determine a proper amount of mixing. For this, this research has designed an optimum mixing ratio and effective manufacturing process. The test on national standard safety and anti-aging and antioxidative functions of the developed cosmetics was conducted to verify effectiveness of developed cosmetics. Also, clinical tests of fulvic acid have referenced and analyzed the data provided by a Japanese fulvic acid supplier.

\subsection{Crude fulvic acid}

\section{Development of functional nourishing cream using fulvic acid}

Fulvic acid-containing solution used in this research was supplied from Japan's Fromearth. This product is an extract of pure humus soil, raw materials collected 20 to $30 \mathrm{~m}$ underground from the western coast of Kyushu, Japan, that has been dried, ground, extracted and filtered, and its contents are as shown in Tables 1, 2 and 3.

Table 1 Basic Information on Fulvic acid

Table 2 Contents of Amino acid in fulvic acid

Table 3 Contents of Mineral in Fulvic Acid 


\subsection{Mixing ratio and design of manufacturing process}

To maintain a chemical balance of cells, fulvic acid acts as a provider or acceptor depending on the cells' needs. It also reinforces the biological usage of nutrients and makes them into an easily dissolvable form in order to prolong the effective time for the recycling of minerals and essential nutrients while absorbing and removing environmental chemical substances before they are accrued and cause damage to cells. For this research, such functions of fulvic acid are maintained as various raw materials are added to design the mixed components as shown in Table 4. Moreover, the manufacturing process, as shown in Fig. 1, has been designed by considering the material components and characteristics of cosmetics containing fulvic acid.

Table 4 Mixture Ratio of Cosmetic Using Fulvic Acid

Figure 1 Manufacturing Process of the cream using Fulvic acid

The first-ever fulvic acid cosmetics, which have been developed based on the mixing components of Table 4 and through the manufacturing process as shown in Fig. 1, felt like glue not being able to soak into the skin during use and also had issues of stickiness, spreadability, viscosity and dryness of the skin could also be clearly felt. As a measure of improvement, additional contents, which contain I.P.M. raw materials (to improve viscosity) and their mixed components have been re-adjusted and the manufacturing process has also been redesigned for stable production. In this research, the final product (fulvic acid complex) of anti-aging functional cosmetics using fulvic acid is as shown in Fig. 2, and the design mixing ratio and manufacturing process are as shown in Tables 5 and 6.

\section{Figure 2Functional Nourishing Cream Using Fulvic acid Table 5Mixing ratio of the final product Table 6 Final fabrication process}

\section{Anti-aging, antioxidative effectiveness test}

To verify the anti-aging and antioxidative functions of the developed fulvic acid complex, this research has conducted various tests including a skin cell safety test, collagen synthesis test, wrinkle improvement-related gene expression analysis test, anti-aging and antioxidative effect test and melanin synthesis inhibition test.

\subsection{Cell culture}

Detroit 511(human skin fibroblast) and HaCaT (human skin keratinocyte) cells were inoculated on the bottom of a culture dish to which a batch of DMEM (Dulbecco's Modified Eagle's Medium) containing penicillin $(100 \mathrm{IU} / \mathrm{ml})$, streptomycin $(100 \mathrm{\mu g} / \mathrm{ml}$ ), and 10\% FBS (fatal bovine serum) was added. This was maintained at $37^{\circ} \mathrm{C}$ and was incubated inside a culture medium containing $5 \% \quad \mathrm{CO}_{2}$.

\subsection{Cell stability test (MTT assay)}

The first stage in exploring the functionality of raw materials of various functional cosmetics is selecting the range of concentration that does not show cytotoxicity in cytoma (Keratinocyte, Melanocyte, Fibroblast, etc.) constituting skin. In such exploration of concentration, a MTT test method is often used to culture these cells and apply experimental substances at various concentration levels in order to investigate their effect on cells' growth, proliferation or toxicity. This analytical method utilizing MTT that specially reacts to cells' mitochondria dehydratases is a more reliable way to evaluate the effect on cell stability.

\subsubsection{Test method}

After dividing Detroit 511(human skin fibroblast) and HaCaT (human skin keratinocyte) cells into 96 well plates at $1 \times 10^{4} /$ well, they were cultured for 24 hours under specified cell culture conditions. The batch was discarded and PBS was used to cleanse it before changing to a new batch and incubating fulvic acid, the testing substance, at the final concentrations of $0.1,1.0,2.0,5.9$ and $10 \mathrm{v} / \mathrm{v} \%$ for 24 hours. For a comparison specimen, $40 \%$ fulvic acid complex ( $2 \%$ greenol, $0.5 \%$ edelweiss extract) was used. $4 \mu l$ of MTT solution $(0.5 \%$ 3-(4,5-dimethyl-2-thiazolyl)-2,5-diphenyl-2H-tetrazolium bromide solution) was added to each well, which was incubated for 4 hours. After removing the culture medium, $200 \mu l$ of dimethyl sulfoxide (DMSO) solution was added and shaken for 10 minutes. Then, $100 \mu l$ from each of the 96 wells was collected and their absorbance were measured by a spectrophotometer at $540 \mathrm{~nm}$. The degree of cytotoxicity was displayed as a percentage of the absorbance strength of a control group that uses pure water.

- Cell viability $(\%)=($ Absorbance of experimental group/absorbance of control group $) * 100$ 


\subsection{Skin cell collagen synthesis acceleration test (using Takara, Cat.\# MK101)}

Collagen is synthesized as procollagen within a cell and, after being secreted to outside of the cell, it is polymerized as collagen fiber. It has been revealed that $\mathrm{N}$ terminus of this procollagen and propetide of $\mathrm{C}$ terminus are isolated by endopeptidase. In this experiment, $\mathrm{C}$ terminus peptide (PIP) special antibody of the Itype human procollagen was used to detect procollagen within the batch secreted from cells as well as procollagen mRNA existing within the cells by using Real-time qPCR.

\subsubsection{Test method}

After dividing Detroit 551 (human skin fibroblast) cells into 48 well plates at $5 * 10^{4} /$ well, they were incubated for 24 hours under specified cell culture conditions. The batch was discarded and PBS was used to cleanse it before changing to a new starvation batch and processing fulvic acid and fulvic acid complex, which are testing substances, to maintain the final concentrations of 1,2 and $5 \mathrm{v} / \mathrm{v} \% .10 \mathrm{ng} / \mathrm{ml} \mathrm{TGF}-\beta 1$ was used as the positive control group.

After 48 hours of material processing, $100 \mu l$ of peroxidase-marked antibody solution was added to each well while the antibody coated microtiter plate was kept in ice. Batches collected from each well of the plate on which cells are spread evenly were centrifuged and then $20 \mu l$ of supernatant was added to each well of the antibody coated microtiter plate before allowing them to react at $37^{\circ} \mathrm{C}$ for 3 hours. The batch was removed and cleansed by $250 \mu l$ of ice-cold PBS 4 times. $100 \mu l$ of substrate solution was added to each well and allowed to react at room temperature for 15 minutes under a completely shaded state. Then, $100 \mu l$ of stop solution $\left(1 \mathrm{~N} \mathrm{H}_{2} \mathrm{SO}_{4}\right)$ was added and absorbance was measured at $450 \mathrm{~nm}$.

\subsection{Collagen and gene expression test using real-time qPCR \\ 3.4.1 Test method}

After dividing Detroit 551 (human skin fibroblast) cells into 96 well plates at $1 * 10^{4} /$ well, they were incubated for 24 hours under specified cell culture conditions. The batch was discarded when the cells were proliferated by more than $80 \%$ and was cleansed with PBS before changing to a new starvation batch and processing fulvic acid and fulvic acid complex, which are testing substances, to maintain the final concentrations of 1,2 and $5 \mathrm{v} / \mathrm{v} \%$, finally being cultured for 24 hours. $10 \mathrm{ng} / \mathrm{ml}$ TGF- $\beta 1$ was used as the positive control group.

For RNA isolation and cDNA synthesis, SuperPrep ${ }^{T M}$ cell lysis \& RT kit for qPCR (TOYOBO, Cat.\# SCQ-101) were used. Cells from which batches had been removed were cleansed one more time with DPBS and $50 \mu l$ of cell lysis mixture (including gDNA remover) was added to react for 5 minutes before adding the stop solution. Then $8 \mu l$ of mRNA, extracted from $32 \mu l$ of RT reaction mixture, was added and cDNA was synthesized by using PCR $\left(37^{\circ} \mathrm{C} 15 \mathrm{~min}, 50^{\circ} \mathrm{C} 5 \mathrm{~min}, 95^{\circ} \mathrm{C} 5 \mathrm{~min}\right)$.

To compare and analyze the expression of genes, cDNA, which was synthesized above, was set as the template and a real-time PCR analysis was conducted by using Thunderbird ${ }^{T{ }^{T}}$ SYBR qPCR Mix (TOYOBO, Cat.\# QPS-201). The primer used in the experiment was normalized by Qiagen's QuantiTect ${ }^{(R)}$ primerassays (PCOLCE; Cat.\# QT01005725) and GAPDH (Cat.\# QT01192646).

- Incidence (fold) $=($ Incidence of specimen processing group $) /($ incidence of control group $)$

\section{Table 7 Real-Time cycler condition}

\subsection{Anti-aging effect by Wound Healing Assay}

As one ages, skin cells experience reduced proliferation and metabolism and may easily be damaged even by a small irritation due to a weak bond between the epidermis and dermis. The wound healing assay process for the assessment of anti-aging effects, observes whether or not a testing substance accelerates the proliferation and migration of cells after a certain period of time in the damaged area.

\subsubsection{Test method}

After dividing $\mathrm{HaCaT}$ (human skin keratinocyte) cells into 12 well plates at $1.5^{*} 10^{5} /$ well, they were incubated for 24 hours under specified cell culture conditions. The batch was discarded when the cells were proliferated by more than $90 \%$ and was cleansed with PBS before changing to a new starvation batch. A scratch was made on each well by using a 200P tip to create a wounded area and fulvic acid and fulvic acid complex, which are testing substances, were processed to maintain the final concentrations of 1,5 and $10 \mathrm{v} / \mathrm{v} \% .100 \mathrm{ng} / \mathrm{ml}$ EGFwas used as the positive control group. After material processing, the image of cells was taken at the $0^{\text {th }}$ hour by a microscope and they were additionally incubated for 16 to 20 more hours. After a specified period of 
time passed, the batch was removed and a fixing solution (4\% paraformaldehyde) was added to be incubated for 15 minutes at room temperature before washing it 3 times with PBS. The degree of wound healing was determined by taking a photo with a microscope and calculating with software called Image J.

\subsection{DPPH (1,1-Diphenyl-2-picryhydrazyl) Assay}

Since it is difficult to test antioxidative effects by free radicals generated within a human body, 1,1Diphenyl-2-picrylhydrazyl (DPPH) is used as the biomarker. A water-soluble, chemically stabilized free radical, DPPH is a purple-colored compound showing characteristic optical absorption at $517 \mathrm{~nm}$. This particular radical is very stable in organic solvents such as alcohol and, when it comes into contact with a substance with antioxidant activity, it gives up electrons and loses radicals (DPPH) as well as its original purple color. It turns yellow, which enables easy observation of oxidation. Because of this, DPPH, an isolated radical that has stabilized the reducing power (antioxidative power) of several kinds of antioxidants as a model of a fatty acid radical, is used and allowed to react with a specific amount of sample solution to test the degree of reduction due to DPPH radicals, being able to directly and indirectly grasp the sample's antioxidation capabilities.

\subsubsection{Test method}

$0.5 \mathrm{ml}$ of $0.1 \mathrm{mM}$ DPPH solution and $0.1 \mathrm{ml}$ of fulvic acid and fulvic acid complex samples, which have been diluted to a specified concentration, were added to $0.4 \mathrm{ml}$ of ethanol. $0.1 \%$ Vitamin $\mathrm{C}$ was used as the positive control group at this time. The samples went through powerful vortexing for 10 seconds before being allowed to react for 30 minutes in a place without much heat and light. Absorbance was measured at $517 \mathrm{~nm}$ by a spectrophotometer, and the degree of antioxidation was expressed as a percentage of the absorbing power of the control group that uses ethanol.

- Free radical activity inhibition rate $(\%)=100-[($ Reaction absorbance of each sample solution/ Reaction absorbance of trial sample solution)*100]

\subsection{Melanocyte-derived melanin synthesis inhibition test}

Tyrosinase is a type of enzyme that biosynthesizes L-tyrosine $\rightarrow$ L-DOPA $\rightarrow$ L-Dopaquinone $\rightarrow$ Dopachrom $\rightarrow$ Melanin by oxidation reaction. Tyrosinase contains a pair of $\mathrm{Cu}$ ions within the active area and, depending on the form of these $\mathrm{Cu}$ ions, is divided into an activated oxy-tyrosinase (including $\mathrm{Cu}$ ions and oxygen) and inactivated deoxy-tyrosinase (only including $\mathrm{Cu}$ ions). First of all, oxy-tyrosinase oxidizes Ltyrosine to form melanin while it itself deoxidizes to become deoxy-tyrosinase. This deoxy-tyrosinase is then supplied with oxygen from cells to turn into oxy-tyrosinase and synthesizes melanin again, which is divided into brown and black Eumelanin and yellow and reddish Pheomelanin depending on the presence of Cysteine. In this experiment, L-Eopaquinone, which is formed from L-tyrosine as the basic substance during the process of building melanin, is detected by absorbance and the activation of tyrosinase is compared.

\subsubsection{Test method}

$0.1 \mathrm{M}$ sodium phosphate buffer $(\mathrm{pH} 6.8)$ as well as fulvic acid and fulvic acid complex at different concentration levels are prepared while the same buffer is used to make $50 \mu g / \mathrm{ml}$ of mushroom tyrosinase before mixing them in 96 well plates as shown in Table 8. Here, 2\% Arbutin was used as the positive control group. Then, $20 \mu l$ of $1.5 \mathrm{mM}$ L-Tyrosine was added to and mixed in each well, which was then incubated at 37 ${ }^{\circ} \mathrm{C}$ for 1 hour using a spectrophotometer, and its absorbance was measured at $490 \mathrm{~nm}$.

\section{Table 8 Test Method}

- Inhibition rate $(\%)=(1-$ absorbance of sample solution/absorbance of control group $) * 100$

\subsection{Cell stability test (MTT assay)}

\section{Cosmetics test results and contemplation}

It was revealed that both cells of Detroit 511(human skin fibroblast) and $\mathrm{HaCaT}$ (human skin keratinocyte) do not affect cell activities at a processing concentration below 10v/v\% (Fig. 3). Based on this result, the maximum processing concentration was set at $10 \mathrm{v} / \mathrm{v} \%$ in the following effect assessment.

\section{Figure 3 Survival rate of the complex in Detroit and HaCaT cells}

\subsection{Skin cell collagen synthesis acceleration test (using Takara, Cat.\# MK101)}

Looking at the amount of collagen's increase within cells of a specimen when Detroit 551 (human skin fibroblast) cells were cultured, this experiment measured the amount of procollagen type I-C-peptide, which is 
secreted to cells' culture medium, to verify its effect on the creation of collagen. As a result, fulvic acid and fulvic acid complex did not show a significant change regardless of concentration levels (Fig. 4).

Figure 4Evaluation of Collagen synthesis by treatment in Detroit 551 cells

\subsection{Collagen and gene expression test using real-time qPCR}

Incidence of genes related to collagen synthesis within Detroit 511 (human skin fibroblast) cells increased depending on the concentration, by more than twice at the $2 \mathrm{v} / \mathrm{v} \%$ processing concentration (Fig. 5). For fulvic acid complex, incidence did not change at the $2 \mathrm{v} / \mathrm{v} \%$ processing concentration but increased by more than twice at the $5 \mathrm{v} / \mathrm{v} \%$ processing concentration. Considering the final concentration of fulvic acid is $2 \mathrm{v} / \mathrm{v} \%$ in a $5 \mathrm{v} / \mathrm{v} \%$ fulvic acid complex, it can be concluded that the increase in incidence of PCOLCE mRNA is due to fulvic acid.

Figure 5 Evaluation of Collagen synthesis related gene expression efficiency in Detroit 551cells

\subsection{Anti-aging effect by Wound Healing Assay}

After spending 18 hours in the control, the healing area increased by about $40 \%$ through proliferation and migration of $\mathrm{HaCaT}$ (human skin keratinocyte) cells and, by EGF, a positive control group, it more than doubled, showing about $80 \%$. By fulvic acid and fulvic acid complex samples, it displayed a better healing area value than the control, confirming that it tends to increase as the concentration is processed at a higher value. When two kinds of samples were process at $10 \mathrm{v} / \mathrm{v} \%$, the healing area of fulvic acid complex increased about 1.2 times more (Fig. 6).

Figure 6 Evaluation of wound healing efficacy of the complex treatment in $\mathrm{HaCaT}$ cells

\subsection{DPPH (1,1-Diphenyl-2-picryhydrazyl) Assay}

As the concentration increased when processing fulvic acid and fulvic acid complex, it was observed that the DPPH free radical elimination ability increased as well (Fig. 7). At the maximum 10v/v\%, it showed a value of about 30 to 40 times greater than the control and, when the two kinds of samples were compared at the same concentration, fulvic acid complex showed a slightly better DPPH free radical elimination ability.

\section{Figure 7 Fulvic acid complex treatment by DPPH free radical scavenging ability}

\subsection{Melanocyte-derived melanin synthesis inhibition test}

It was shown that, while activation of tyrosinase was inhibited by about $50 \%$ in $2 \mathrm{v} / \mathrm{v} \%$ Arbutin, the positive control group, fulvic acid and fulvic acid complex samples did not have a significant influence on the activation of tyrosinase (Fig. 8).

Figure 8 Evaluation of Tyrosinase inhibition activity by the treatment

\section{Fulvic acid cosmetics' harmfulness test on the environment and human body}

To evaluate the stability of fulvic acid cosmetics developed in this research, additional safety tests have been conducted at on 5 items (lead, arsenic, mercury, methanol, etc.), which are the criteria of quality assessment in cosmetics testing by the Ministry of Food \& Drug Safety, and they have passed all the inspection criteria (Table 9).

Table 9 Safety test result

\section{Conclusion}

This research has developed functional cosmetics for the prevention of skin aging by using fulvic acid, a natural humic substance that is known for excellent whitening and wrinkle improvement demanded in the market. The conclusion is as follows.

First, adenosine, edelweiss-cultured natural extracts, Niacinamide, Bio-AHP 500H, etc., all of which are functional materials for wrinkle and whitening effect enhancement, were mixed with fulvic acid to minimize the effective chelate reaction, and an optimum mixing ratio was designed in order to create a sufficient amount of fulvic acid effect.

Second, a manufacturing process for the stable production of products was proposed with a number of variables, including weight-measuring scale, stirring Agi (RPM and time) adjustment, elevation of dissolution temperature and timing for insertion of emulsifiers, all of which are performed for a smooth chelate reaction of 
crude fulvic acid solution, functional substances and glycerin.

Third, the performance of cosmetics developed in this research have been verified by a series of tests including a skin cell safety test, collagen synthesis test, wrinkle improvement-related gene expression analysis test, anti-aging and antioxidative effect test and melanin synthesis inhibition test, and the results showed an outstanding level of performance.

Fourth, safety tests have been conducted on 5 items (lead, arsenic, mercury, methanol, etc.), which are the criteria of quality assessment in cosmetics testing by the Ministry of Food \& Drug Safety, and they have passed all the inspection criteria.

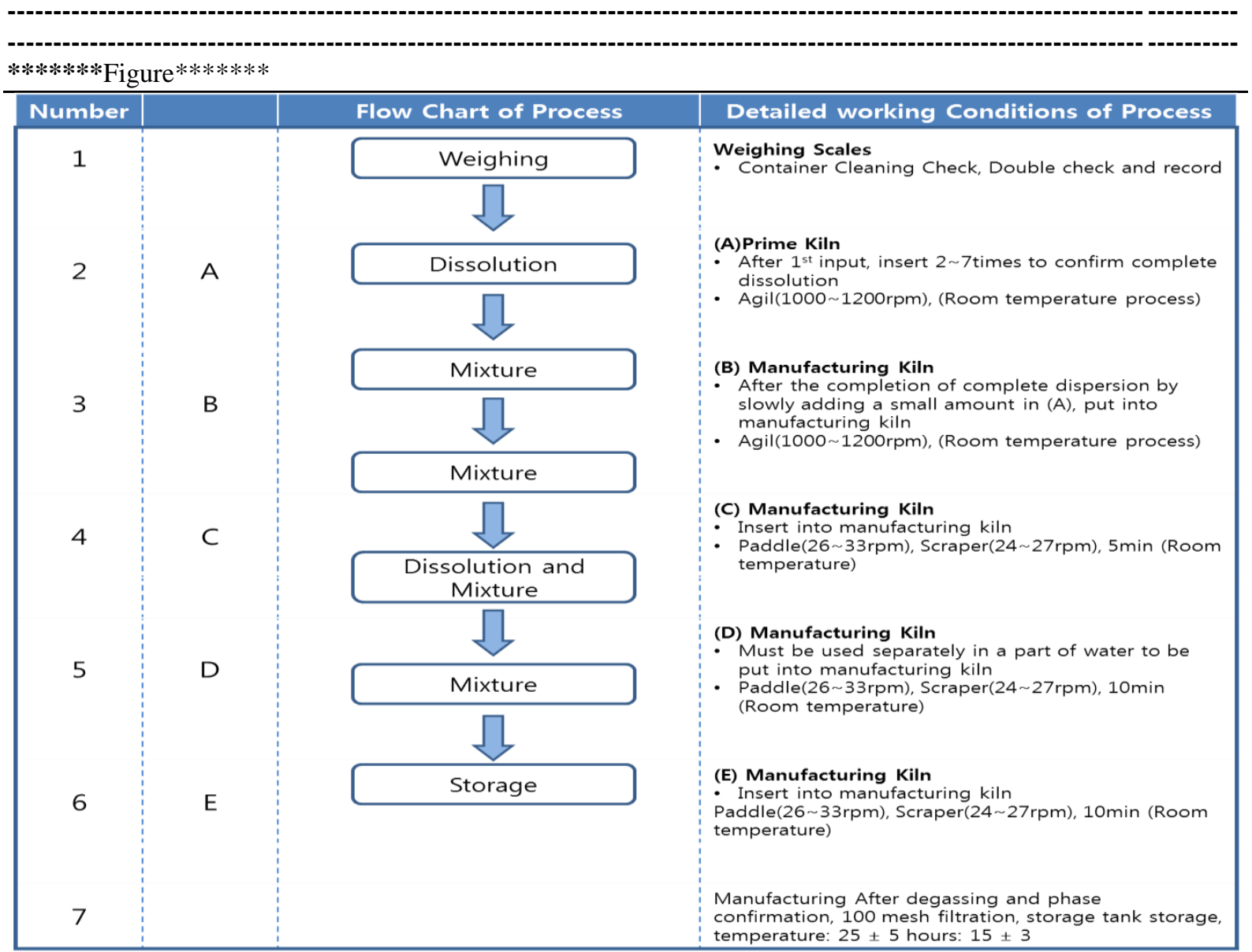

Figure 1 Manufacturing Process of the cream using Fulvic acid
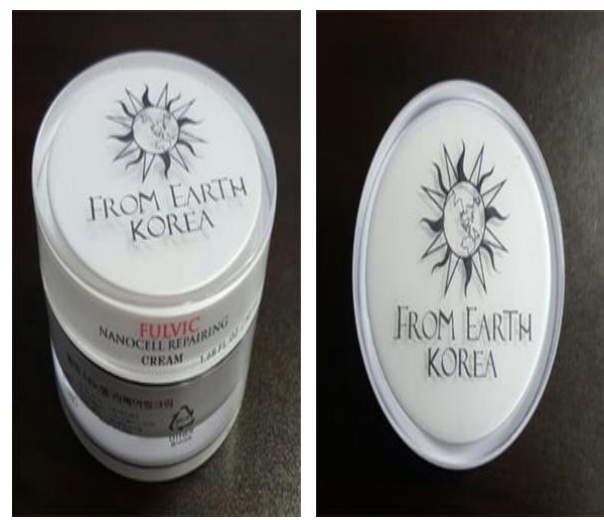

Figure 2Functional Nourishing Cream Using Fulvic acid 
Detroit511 (human skin fibroblast)

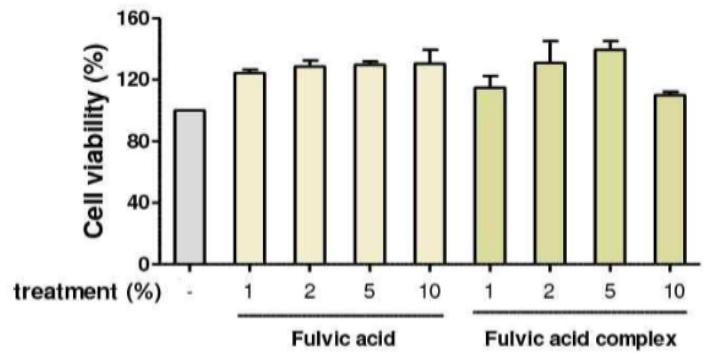

\begin{tabular}{|c|c|c|c|c|c|c|c|c|c|}
\hline \multirow{2}{*}{ treatment } & \multirow{2}{*}{ Control } & \multicolumn{4}{|c|}{ Fulvic acid } & \multicolumn{4}{|c|}{ Fulvic acid complex } \\
\cline { 3 - 10 } & $1 \%$ & $2 \%$ & $5 \%$ & $10 \%$ & $1 \%$ & $2 \%$ & $5 \%$ & $10 \%$ \\
\hline $\begin{array}{c}\text { Average } \\
(\%)\end{array}$ & 100.0 & 124.3 & 128.4 & 129.5 & 130.4 & 114.7 & 130.9 & 139.5 & 109.9 \\
\hline
\end{tabular}

$\mathrm{HaCaT}$ (human skin keratinocyte)

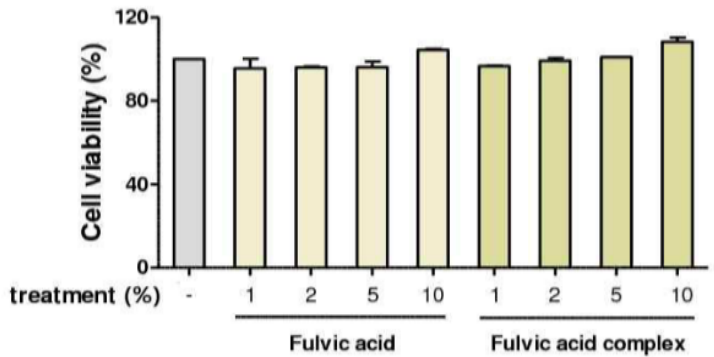

\begin{tabular}{|c|c|c|c|c|c|c|c|c|c|}
\hline \multirow{2}{*}{ treatment } & \multirow{2}{*}{ Control } & \multicolumn{5}{|c|}{ Fulvic acid } & \multicolumn{4}{|c|}{ Fulvic acid complex } \\
\cline { 3 - 10 } & $1 \%$ & $2 \%$ & $5 \%$ & $10 \%$ & $1 \%$ & $2 \%$ & $5 \%$ & $10 \%$ \\
\hline $\begin{array}{c}\text { Average } \\
(\%)\end{array}$ & 100.0 & 95.5 & 95.9 & 96.0 & 104.3 & 96.7 & 99.2 & 100.8 & 108.3 \\
\hline
\end{tabular}

Figure 3 Survival rate of the complex in Detroit and $\mathrm{HaCaT}$ cells

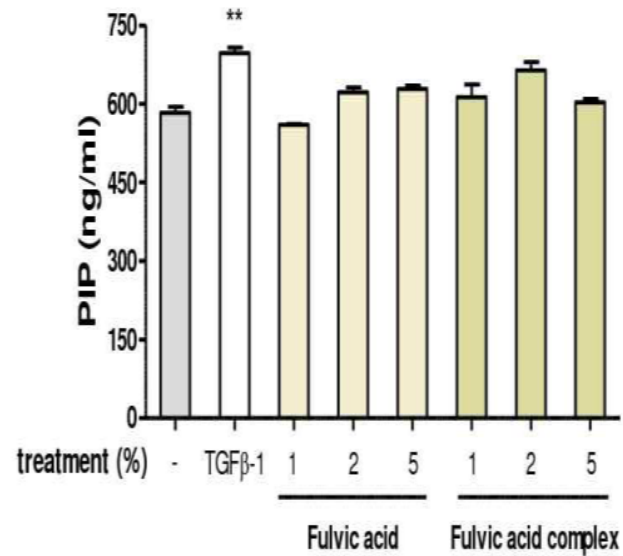

\begin{tabular}{|l|c|c|c|c|c|c|c|c|}
\hline \multirow{2}{*}{ treatment } & \multirow{2}{*}{ Control } & Positive & \multicolumn{3}{|c|}{ Fulvic acid } & \multicolumn{3}{|c|}{ Fulvic acid complex } \\
\cline { 5 - 8 } & & control & $1 \%$ & $2 \%$ & $5 \%$ & $1 \%$ & $2 \%$ & $5 \%$ \\
\hline $\begin{array}{l}\text { Average } \\
\text { (ng/m) }\end{array}$ & 583 & 697 & 561 & 622 & 628 & 613 & 664 & 602 \\
\hline
\end{tabular}

Figure 4 Evaluation of Collagen synthesis by treatment in Detroit 551 cells 


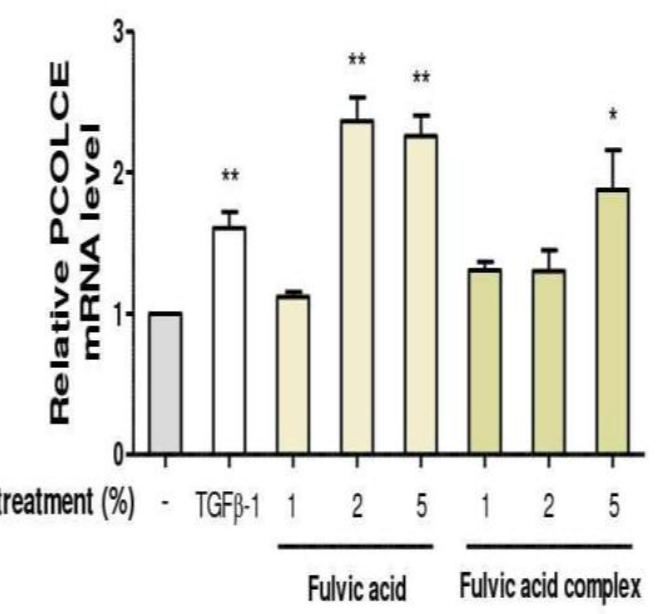

\begin{tabular}{|l|c|c|c|c|c|c|c|c|}
\hline \multirow{2}{*}{ treatment } & \multirow{2}{*}{ Control } & Positive & \multicolumn{3}{|c|}{ Fulvic acid } & \multicolumn{3}{|c|}{ Fulvic acid complex } \\
\cline { 4 - 9 } & & control & $1 \%$ & $2 \%$ & $5 \%$ & $1 \%$ & $2 \%$ & $5 \%$ \\
\hline Average & 1.000 & 1.607 & 1.117 & 2.363 & 2.257 & 1.307 & 1.300 & 1.877 \\
\hline
\end{tabular}

Figure 5 Evaluation of Collagen synthesis related gene expression efficiency in Detroit 551cells
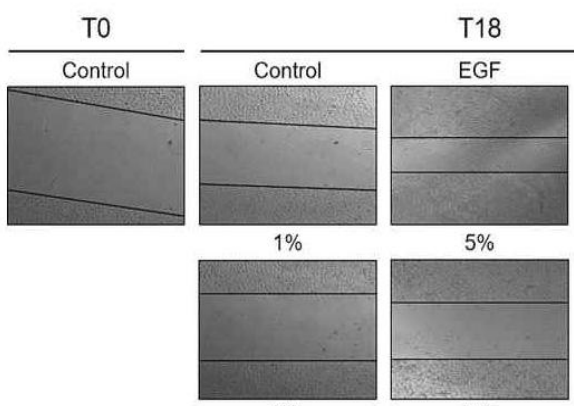

$10 \%$
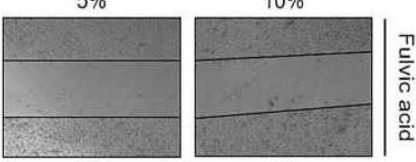

$5 \%$

$10 \%$
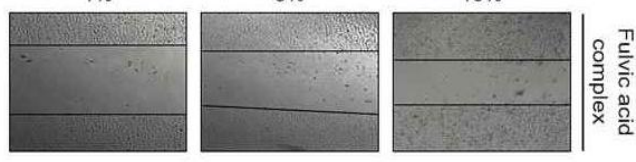

T18

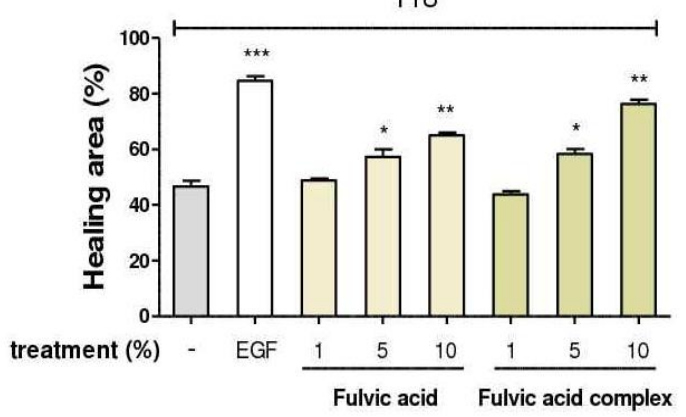

\begin{tabular}{|c|c|c|c|c|c|c|c|c|}
\hline \multirow{2}{*}{ treatment } & \multirow{2}{*}{ Control } & Positive & \multicolumn{3}{|c|}{ Fulvic acid } & \multicolumn{3}{|c|}{ Fulvic acid complex } \\
\cline { 4 - 8 } & & control & $1 \%$ & $2 \%$ & $5 \%$ & $1 \%$ & $2 \%$ & $5 \%$ \\
\hline $\begin{array}{c}\text { Average } \\
\text { (\%) }\end{array}$ & 46.6 & 84.6 & 48.8 & 57.2 & 65.0 & 43.8 & 58.4 & 76.4 \\
\hline
\end{tabular}

Figure 6 Evaluation of wound healing efficacy of the complex treatment in HaCaT cells 


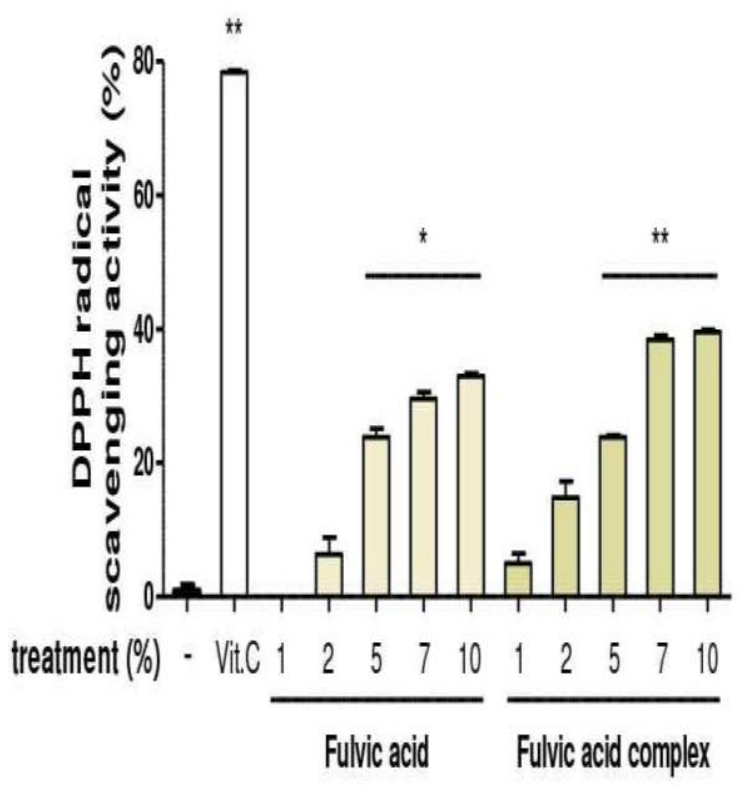

\begin{tabular}{|c|c|c|c|c|c|c|c|c|c|c|c|c|}
\hline treatment & Control & Positive & \multicolumn{5}{|c|}{ Fulvic acid } & \multicolumn{5}{|c|}{ Fulvic acid complex } \\
\cline { 4 - 13 } & control & $1 \%$ & $2 \%$ & $5 \%$ & $7 \%$ & $10 \%$ & $1 \%$ & $2 \%$ & $5 \%$ & $7 \%$ & $10 \%$ \\
\hline $\begin{array}{c}\text { Average } \\
(\%)\end{array}$ & 0.9 & 78.4 & -3.0 & 6.4 & 23.9 & 29.6 & 33.0 & 5.0 & 14.9 & 23.9 & 38.4 & 39.6 \\
\hline
\end{tabular}

Figure 7 Fulvic acid complex treatment by DPPH free radical scavenging ability

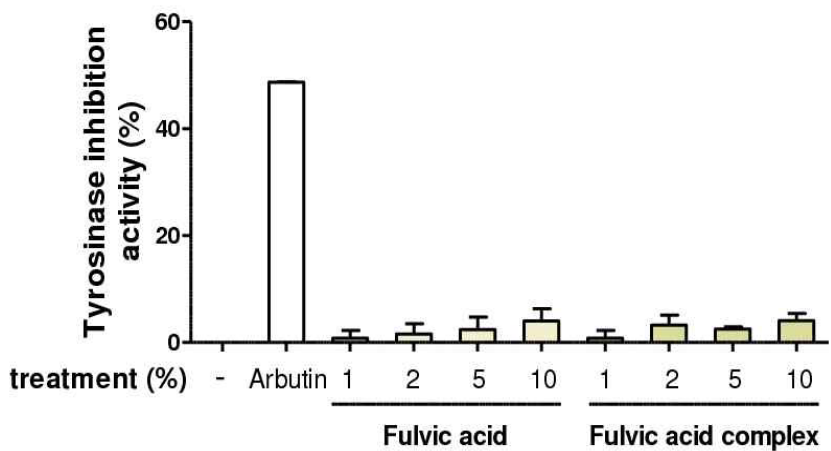

\begin{tabular}{|c|c|c|c|c|c|c|c|c|c|c|}
\hline \multirow{2}{*}{ treatment } & \multirow{2}{*}{ Control } & $\begin{array}{c}\text { Positive } \\
\text { control }\end{array}$ & \multicolumn{4}{|c|}{ Fulvic acid } & \multicolumn{4}{|c|}{ Fulvic acid complex } \\
\hline $\begin{array}{c}\text { Average } \\
\text { (\%) }\end{array}$ & 0.0 & 48.7 & 0.8 & 1.6 & 2.4 & 4.0 & 0.8 & 3.3 & 2.5 & 4.1 \\
\hline
\end{tabular}

Figure 8 Evaluation of Tyrosinase inhibition activity by the treatment $* * * * * * * T a b l e * * * * * * *$

Table 1 Basic Information on Fulvic acid

\begin{tabular}{|l|l|}
\hline Item & Value \\
\hline $\mathrm{pH}$ & $2.7 \sim 2.8$ \\
\hline Specific Gravity & 1.003 \\
\hline Evaporation Residue & $0.3 \mathrm{w} / \mathrm{v} \%$ \\
\hline Ignition Residue & $0.2 \mathrm{w} / \mathrm{v} \%$ \\
\hline Heavy Metal & Under $20 \mathrm{ppm}$ \\
\hline Arsenic & Under $2 \mathrm{ppm}$ \\
\hline Nitrogen & $0.001 \%$ \\
\hline Fulvic acid & $30.6 \mathrm{mg} / \mathrm{L}$ \\
\hline
\end{tabular}


Table 2 Contents of Amino acid in Fulvic acid

\begin{tabular}{|l|l|}
\hline Item & Value \\
\hline partic acid & $90 \mathrm{ppm}$ \\
\hline anine & $41 \mathrm{ppm}$ \\
\hline ginine & $94 \mathrm{ppm}$ \\
\hline leucine & $44 \mathrm{ppm}$ \\
\hline ycine & $34 \mathrm{ppm}$ \\
\hline utamic Acid & $55 \mathrm{ppm}$ \\
\hline steine & $\mathrm{A}$ \\
\hline reonin & $41 \mathrm{ppm}$ \\
\hline rine & $16 \mathrm{ppm}$ \\
\hline line & $372 \mathrm{ppm}$ \\
\hline stidine & $03 \mathrm{ppm}$ \\
\hline enylalanine & $50 \mathrm{ppm}$ \\
\hline llin & $31 \mathrm{ppm}$ \\
\hline sin & $31 \mathrm{ppm}$ \\
\hline ucine & $46 \mathrm{ppm}$ \\
\hline aminobutyric acid & $0.02 \mathrm{ppm}$ \\
\hline aminoisobutyric aciduria & $0.02 \mathrm{ppm}$ \\
\hline alanine & $54 \mathrm{ppm}$ \\
\hline aminobutyric acid & $32 \mathrm{ppm}$ \\
\hline nithine & $73 \mathrm{ppm}$ \\
\hline stathionine & $74 \mathrm{ppm}$ \\
\hline droxylysine & $60 \mathrm{ppm}$ \\
\hline ssHerselin & $77 \mathrm{ppm}$ \\
\hline
\end{tabular}

Table 3Contents of Mineral in Fulvic Acid

\begin{tabular}{|l|l|}
\hline Categories & Analysis Value \\
\hline (Aluminum) & $4 \mathrm{mg} / \mathrm{L}$ \\
\hline Boron) & $5 \mathrm{mg} / \mathrm{L}$ \\
\hline (Calcium) & $8 \mathrm{mg} / \mathrm{L}$ \\
\hline (Cerium) & $00 \mathrm{mg} / \mathrm{L}$ \\
\hline (Cobalt) & $25 \mathrm{mg} / \mathrm{L}$ \\
\hline (Iron) & $4 \mathrm{mg} / \mathrm{L}$ \\
\hline Potassium) & $11 \mathrm{mg} / \mathrm{L}$ \\
\hline (Lanthanum) & $37 \mathrm{mg} / \mathrm{L}$ \\
\hline (Lithium) & $8 \mathrm{mg} / \mathrm{L}$ \\
\hline g (Magnesium) & $2 \mathrm{mg} / \mathrm{L}$ \\
\hline (Manganese) & $14 \mathrm{mg} / \mathrm{L}$ \\
\hline (Sodium) & $4 \mathrm{mg} / \mathrm{L}$ \\
\hline (Scandium) & $2 \mathrm{mg} / \mathrm{L}$ \\
\hline (Silicon) & $7 \mathrm{mg} / \mathrm{L}$ \\
\hline (Yttrium) & $2 \mathrm{mg} / \mathrm{L}$ \\
\hline (Zinc) & $7 \mathrm{mg} / \mathrm{L}$ \\
\hline
\end{tabular}

Table 4 Mixture Ratio of Cosmetic using Fulvic Acid

\begin{tabular}{|l|l|l|l|}
\hline & No. & Name of the material & $\begin{array}{l}\text { WT } \\
(\%)\end{array}$ \\
\hline \multirow{4}{*}{ A } & 1 & DI-Water & 26.90 \\
\cline { 2 - 4 } & 2 & Fulvic Acid & 50.00 \\
\cline { 2 - 4 } & 3 & Glycein & 8.00 \\
\cline { 2 - 4 } & 4 & $1,3-$ BG & 6.00 \\
\cline { 2 - 4 } & 5 & $\begin{array}{l}\text { Natural Extract BP20(Genencare } \\
\text { OSMS BA) }\end{array}$ & 2.00 \\
\cline { 2 - 4 } & 6 & Trehalose & 1.00 \\
\cline { 2 - 4 } & 7 & Steviten-Lico DPG & 0.05 \\
\hline \multirow{3}{*}{ B } & 1 & LECINOL S-PIE & 0.14 \\
\cline { 2 - 4 } & 2 & Carbopol 940 & 0.80 \\
\hline C & 1 & Jojoba Oil & 0.01 \\
\cline { 2 - 4 } & 2 & Vitamin E-Acetate & 0.80 \\
\hline D & 1 & TROMETHAMINE & 0.10 \\
\hline E & 1 & Haiaqueouster DCS & 0.20 \\
\cline { 2 - 4 } & 2 & 1,2-Hexanediol & \\
\cline { 2 - 4 } & 3 & Dermosoft Octiol & \\
\hline
\end{tabular}


Table 5 Mixing ratio of a final product

\begin{tabular}{|l|l|l|l|}
\hline & No. & Material & WT (\%) \\
\hline \multirow{4}{*}{ A } & 1 & DI-Water & 17.01 \\
\cline { 2 - 4 } & 2 & Skull filler ampule feedstock & 8.00 \\
\cline { 2 - 4 } & 3 & Fulvic Acid & 50.00 \\
\cline { 2 - 4 } & 4 & Glycein & 8.00 \\
\cline { 2 - 4 } & 5 & $1,3-$ BG & 6.00 \\
\cline { 2 - 4 } & 6 & $\begin{array}{l}\text { Natural Extract BP20(Genencare } \\
\text { OSMS BA) }\end{array}$ & 1.50 \\
\cline { 2 - 4 } & 7 & Trehalose & 1.00 \\
\hline \multirow{4}{*}{ B } & 8 & Steviten-Lico DPG & 0.04 \\
\cline { 2 - 4 } & 1 & LECINOL S-PIE & 0.14 \\
\hline C & 2 & Aristoflex AVC & 1.00 \\
\cline { 2 - 4 } & 2 & J.P.M & 0.00 \\
\cline { 2 - 4 } & 3 & Vitamin E-Acetate & 0.00 \\
\hline D & 1 & Haiaqueouster DCS & 0.10 \\
\cline { 2 - 4 } & 2 & 1,2-Hexanediol & 0.01 \\
\cline { 2 - 4 } & 3 & Dermosoft Octiol & \\
\cline { 2 - 4 } & 4 & FR.(LAVENDER R10229) & \\
\hline
\end{tabular}

Table 6 Final fabrication process

\begin{tabular}{|c|c|c|}
\hline & & Detailed working conditions by process \\
\hline 1 & & $\begin{array}{l}\text { Weighing Process } \\
\text { Container Cleaning check, double check and record }\end{array}$ \\
\hline 2 & A & $\begin{array}{l}\text { Melting Process(Water Kiln) } \\
1 \text { After input, insert } 2 \sim 6 \text { times to confirm complete } \\
\text { dissolution } \\
\text { - Agi(1000 1200rpm), Room temperature }\end{array}$ \\
\hline 3 & B & $\begin{array}{l}\text { Mixing process(Manufacturing Kiln) } \\
\text { Weighed separately and slowly added to the A phase in } \\
\text { small amounts to confirm complete dispersion and then } \\
\text { put into the manufacturing kiln } \\
\text { - Agi(1000 1200rpm), Room Temperature }\end{array}$ \\
\hline 4 & $\mathrm{C}$ & $\begin{array}{l}\text { - Mixing process(Manufacturing Kiln) } \\
\text { Weigh separately and put into the manufacturing kiln } \\
\text { - Paddle(26 33rpm) } \\
\text { - Scraper(24 27rpm) } \\
\text { - } 5 \text { min, Room temperature }\end{array}$ \\
\hline 5 & $\mathrm{D}$ & $\begin{array}{l}\text { Melting and mixing process (Manufacturing Kiln) } \\
\text { Weigh separately and put into the manufacturing kiln } \\
\text { - Paddle(26 33rpm) } \\
\text { - Scraper(24 27rpm) } \\
\text { - } 10 \text { min, Room temperature }\end{array}$ \\
\hline 6 & & $\begin{array}{l}\text { Storage process } \\
\text { Defoamation of the kiln and storage } \\
\text { - Temperature } 25 \pm 5^{\circ} \mathrm{C}\end{array}$ \\
\hline
\end{tabular}

Table 7 Real-time cycler conditions

\begin{tabular}{|l|l|l|}
\hline Step & Time & Temperature \\
\hline Reverse transcription & $30 \mathrm{~min}$ & $50^{\circ} \mathrm{C}$ \\
\hline PCR initial activation step & $15 \mathrm{~min}$ & $95^{\circ} \mathrm{C}$ \\
\hline 3-step cycling & $15 \mathrm{~s}$ & $94^{\circ} \mathrm{C}$ \\
\hline Denaturation & $30 \mathrm{~s}$ & $60^{\circ} \mathrm{C}$ \\
\hline Annealing & $30 \mathrm{~s}$ & $72^{\circ} \mathrm{C}$ \\
\hline Extension & 45 & \\
\hline Number of cycles & \multicolumn{2}{|l}{} \\
\hline
\end{tabular}


Table 8 Test Method

\begin{tabular}{|l|l|l|l|}
\hline & Sample & Blank & $\begin{array}{l}\text { Positive } \\
\text { control }\end{array}$ \\
\hline $\begin{array}{l}\text { Sodium phosphate } \\
\text { buffer(pH6.8) }\end{array}$ & $50 \mu l$ & $60 \mu l$ & $50 \mu l$ \\
\hline Mushroom tyrosinase & $20 \mu l$ & - & $20 \mu l$ \\
\hline Test Substance & $10 \mu l$ & - & $10 \mu l$ \\
\hline
\end{tabular}

Table 9 Safety test result

\begin{tabular}{|l|l|l|}
\hline $\begin{array}{l}\text { Inspection } \\
\text { items }\end{array}$ & $\begin{array}{l}\text { Test and inspection } \\
\text { standards }\end{array}$ & Examination result \\
\hline Lead & $20 \mathrm{mg} / \mathrm{kg}$ & Non-detected \\
\hline Arsenic & $10 \mathrm{mg} / \mathrm{kg}$ & Non-detected \\
\hline Mercury & $1 \mathrm{mg} / \mathrm{kg}$ & Non-detected \\
\hline Stibium & $10 \mathrm{mg} / \mathrm{kg}$ & Non-detected \\
\hline Cadmium & $5 \mathrm{mg} / \mathrm{kg}$ & Non-detected \\
\hline
\end{tabular}

\section{References}

[1]. Carmen Donisa, Raluca Mocanu, and Eiliv Steinnesl (2003) Distribution of some major and minor elements between fulvic and humic acid fractions in natural soils. Science direct. Geoderma 111, 75-84.

[2]. Syuntaro Hiradate, Takuya Yonezawa and Hiroshi Takesako (2006) Isolation and purification of hydrophilic fulvic acids by precipitation. Science direct. Geoderma 132: 196-205.

[3]. Daqing Gan, Shaban, I. Kotob, and Daman, S. Walia (2007) Evaluation of a spectrophotometric method for practical and cost effective quantification of fulvic acid. Annals of Environmental Science. 1: 11-15.

[4]. Rauthan, B. S. and M. Schnitzer (1981) Effects of a soil fulvic acid on the growth and nutrient content of cucmber (cucumis sativus) plants. Plant Soil. 63: 491-495.

List of Figures

Figure 1 Manufacturing Process of the cream using Fulvic acid

Figure 2 Functional Nourishing Cream Using Fulvic acid

Figure 3 Survival rate of the complex in Detroit and HaCaT cells

Figure 4 Evaluation of Collagen synthesis by treatment in Detroit 551 cells

Figure 5 Evaluation of Collagen synthesis related gene expression efficiency in Detroit 551cells

Figure 6 Evaluation of wound healing efficacy of the complex treatment in HaCaT cells

Figure 7 Fulvic acid complex treatment by DPPH free radical scavenging ability

Figure 8 Evaluation of Tyrosinase inhibition activity by the treatment

List of tables

Table 1 Basic Information on Fulvic acid

Table 2 Contents of Amino acid in fulvic acid

Table 3 Contents of Mineral in Fulvic Acid

Table 4 Mixture Ratio of Cosmetic Using Fulvic Acid

Table 5 Mixing ratio of the final product

Table 6 Final fabrication process

Table 7 Real-Time cycler condition

Table 8 Test Method

Table 9 Safety test result 